\title{
hCG $\beta$ core fragment is a metabolite of hCG: evidence from infusion of recombinant hCG
}

\author{
R J Norman, M-M Buchholz, A A Somogyi ${ }^{\mathbf{1}}$ and F Amato \\ Reproductive Medicine Unit, Department of Obstetrics and Gynaecology, University of Adelaide, The Queen Elizabeth Hospital, Adelaide, \\ South Austrailia 5011, Australia \\ ${ }^{1}$ Department of Clinical and Experimental Pharmacology, University of Adelaide, South Australia 5005, Australia \\ (Requests for offprints should be addressed to R J Norman, Reproductive Medicine Unit, Department of Obstetrics and Gynaecology, The Queen Elizabeth \\ Hospital, 28 Woodville Road, Woodville, South Australia 5011, Australia; E-mail: rnorman@medicine.adelaide.edu.au)
}

\begin{abstract}
The availability of recombinant human chorionic gonadotrophin ( $\mathrm{r}-\mathrm{hCG})$ has allowed us to measure its metabolic and renal clearance rates and to study the origin of the $\beta$ core fragment of hCG (hCG $\beta c f$ ). Serum and urine samples were collected from six subjects, after an intravenous injection of $2 \mathrm{mg}$ (equivalent to $44000 \mathrm{IU}$ Urinary hCG) r-hCG, and assayed for hCG and the beta subunit (hCG $\beta$ ). Urine from four of the subjects was also subjected to gel chromatography and assayed for hCG $\beta c f$ and hCG.

$\mathrm{r}-\mathrm{hCG}$, administered as an intravenous dose, was distributed, initially in a volume of $3.4 \pm 0.71$ (mean \pm s.D.) and then in $6 \cdot 5 \pm 1 \cdot 151$ at steady-state. The disappearance of $\mathrm{r}-\mathrm{hCG}$ from serum was bi-exponential, with an
\end{abstract}

initial half-life of $4.5 \pm 0.7 \mathrm{~h}$ and a terminal half-life of $29 \cdot 0 \pm 4 \cdot 6 \mathrm{~h}$. The mean residence time was $28 \cdot 6 \pm$ $3.6 \mathrm{~h}$ and the total systemic clearance rate of $\mathrm{r}-\mathrm{hCG}$ was $226 \pm 18 \mathrm{ml} / \mathrm{h}$. The renal clearance rate was $28.75 \pm 6.2 \mathrm{ml} / \mathrm{h}$ (mean \pm s.D). hCG $\beta$ cf was detected in all urine samples collected at $6 \mathrm{~h}$ intervals. Over the $138 \mathrm{~h}$ period of urine collection, $12 \cdot 9 \%$ (range $10 \cdot 1-17 \cdot 3 \%$ ) of $\mathrm{r}-\mathrm{hCG}$ injected was recovered as the intact molecule and $1 \cdot 7 \%$ (range $0 \cdot 8-2 \cdot 9 \%$ ) was recovered as the hCG $\beta \mathrm{cf}$, in 4 subjects. The molar ratio of hCG $\beta$ cf to hCG in urine increased from $3 \cdot 1 \pm 1 \cdot 7 \%$, on day 1 , to $76 \pm 34 \cdot 3 \%$ (mean \pm s.E.M.) on day 5 , after $r-h C G$ infusion, suggesting that $\mathrm{hCG} \beta \mathrm{cf}$ is a metabolic product of the infused $\mathrm{r}-\mathrm{hCG}$. Journal of Endocrinology (2000) 164, 299-305

\section{Introduction}

Human chorionic gonadotrophin (hCG), produced by the syncytiotrophoblast cells of the placenta, consists of $\alpha$ and $\beta$ subunits which are produced separately from distinct genes and subsequently combine to form the dimeric molecule. Throughout pregnancy the free $\alpha$ and free $\beta$ subunits are secreted into the plasma in addition to the intact hCG. At present, it is generally considered that these subunits do not perform any significant biological activity.

Previous studies on the pharmacokinetics and metabolism of hCG have indicated a multi-exponential disappearance curve in serum (Midgely \& Jaffe 1968, Yen et al. 1968, Rizkallah et al. 1969, Wehmann \& Nisula 1981, Korhonen et al. 1997) and that only $17-28 \%$ of the serum hCG is excreted in the urine as the intact heterodimeric form (Wide et al. 1968, Wehmann \& Nisula 1981). In addition to a wide range of heterogeneous forms of intact hCG, the urine of pregnant females contains free $\alpha$ and free $\beta$ subunits, nicked hCG (missing linkages in the $\beta 41-54$ region) (Puisieux et al. 1990, Birken et al. 1991, Kardana et al. 1991) and C-terminal forms, i.e. fragments of the $\beta$ chain (Amr et al. 1983) and hCG $\beta$ cf (Kato \& Braunstein 1988, Birken et al. 1988).

The quantitatively major urinary product, the $\beta$ core fragment of hCG (hCG $\beta \mathrm{cf}$ ), has an apparent molecular weight of $12-14 \mathrm{kDa}$, with a protein core of 73 amino acids. Structurally, it consists of two polypeptide chains, the $\beta$ amino acids $55-92$ and $\beta$ amino acids $6-40$ covalently linked by disulphide bonds. However, it lacks the immunodeterminant of hCG $\beta$. hCG $\beta$ cf has also been found in the urine of nonpregnant patients with trophoblastic disease or cancer, in the absence of detectable concentrations of plasma hCG (Kardana et al. 1988). Consequently hCG $\beta c f$ has been used as a cancer marker, particularly for gynaecological tumours. The origins of hCG $\beta c f$ are uncertain. It has been assumed that it originates from the renal metabolism of intact or free hCG $\beta$, as demonstrated in the rat (Lefort et al. 1986). However, there are reports of its secretion by placental tissue in culture (Cole \& Birken 1988).

Previous studies have been complicated because pure hCG has not been available (all hCG was of urinary origin, where hCG $\beta c f$ is a known contaminant). The recent 
availability of recombinant hCG ( $\mathrm{r}-\mathrm{hCG}$ ) has allowed us to investigate the production of hCG $\beta \mathrm{cf}$ from the metabolism of pure r-hCG. In addition, it has allowed us to study the pharmacokinetics of the recombinant hormone and compare the data with the results of previous studies that have used urinary-derived hCG.

\section{Materials and Methods}

\section{Protocol}

Six healthy non-pregnant female volunteers aged 17-45 years, with normal menstrual cycles and no known liver or kidney disorders were recruited. Following informed consent, volunteers in their follicular phase received an intravenous bolus ( $2 \mathrm{mg}$; equivalent to approximately $44000 \mathrm{IU}$ urinary hCG) of r-hCG (Ovidrel; Serono Australia Pty. Ltd, Frenchs Forest, NSW 2086, Australia) via a saline drip over a $3 \mathrm{~min}$ period. The hormone was administered within $5 \mathrm{~min}$ from when the lyophilized material was reconstituted.

The first two subjects had blood samples collected from the opposite arm every $5 \mathrm{~min}$ for the first hour, every $10 \mathrm{~min}$ for the next $2 \mathrm{~h}$, every $20 \mathrm{~min}$ for the next $6 \mathrm{~h}$, at 2-hourly intervals for the next $24 \mathrm{~h}$ and at 6-hourly intervals for the next $72 \mathrm{~h}$. Total urine excretion was collected at hourly intervals for the first $6 \mathrm{~h}, 2$ hourly intervals for the next 26-h and at 12-hourly intervals up until 7 days after infusion. The other four subjects had blood samples collected every $5 \mathrm{~min}$ for the first $15 \mathrm{~min}$, every $15 \mathrm{~min}$ for the next $45 \mathrm{~min}$, every $30 \mathrm{~min}$ for the next $10 \mathrm{~h}$, hourly for the next $3 \mathrm{~h}$, followed by blood collection at $11,15,21,29,39,51,75,87$ and $105 \mathrm{~h}$ after infusion. Total urine samples were collected at 6 hourly intervals up to 7 days after infusion. All sera and urine samples were each aliquotted into four separate containers to avoid multiple freeze-thaw steps when each sample was assayed for hCG, hCG $\beta$ or chromatographed and stored at $-20^{\circ} \mathrm{C}$.

The study was approved by the Human Ethics Committee at The Queen Elizabeth Hospital.

\section{Gel filtration}

r-hCG, hCG $\beta$ (CR125; provided by the National Institutes of Health, National Institute of Child Health and Human Development, Bethesda, MD, USA) and purified hCG $\beta$ cf (de Medeiros et al. 1992a) were initially chromatographed to establish their elution profile on a Superdex 75 column $(1.6 \times 60 \mathrm{~cm}$; Amersham Pharmacia Biotech, Uppsala, Sweden) preequilibrated and run with $150 \mathrm{mM}$ ammonium bicarbonate at a flow rate of $1 \mathrm{ml} / \mathrm{min}$. One millilitre fractions were collected, desalted and assayed for the individual hormones. When $\mathrm{r}-\mathrm{hCG}(167 \mu \mathrm{g}$ in $1 \mathrm{ml}$ $150 \mathrm{mM}$ ammonium bicarbonate) was subjected to gel filtration, fractions corresponding to the purified hCG $\beta$ cf peak were pooled, desalted and assayed for hCG $\beta c f$. The pooled sample was then rechromatographed for confirmation of hCG $\beta$ cf.

Twenty millilitres of each urine collection was concentrated 5 to 13 times using Macrosep centrifugal concentrators with a 3000 molecular weight cut-off membrane (Pall Filtron, Northborough, MA, USA). Concentration of the samples allowed the detection of the hormones in very dilute samples following gel filtration, as described above. The chromatography fractions were desalted by repeated lyophilysation and reconstitution with deionised water, and then were finally reconstituted in $50 \mathrm{mM}$ phosphate buffer, $\mathrm{pH} 7 \cdot 4$, containing $0 \cdot 5 \%$ bovine serum albumin and $0.05 \%$ sodium azide.

\section{Immunoassays}

hCG immunoreactivity in $\mathrm{r}-\mathrm{hCG}$, serum, urine and chromatography fractions was measured with the commercial Tandem-R hCG immunoradiometric assay (IRMA) (Hybritech Inc., San Diego, CA, USA) according to the manufacturer's protocol. The assay, which has a limit of detection of $1.5 \mathrm{mIU} / \mathrm{ml}$ and a working range of 5 to $400 \mathrm{mIU} / \mathrm{ml}$, has been reported to detect both nicked hCG and non-nicked hCG (Cole 1997). hCG was assigned a molecular weight value of $38 \mathrm{kDa}$ and a conversion factor of $1 \mathrm{IU}=1 \cdot 2$ pmoles was used to convert the results to molar equivalents.

The free $\beta$-subunit of hCG (hCG $\beta$ ) in the same samples was determined by the Amerlex-M free hCG $\beta$ IRMA kit (Biclone Australia Pty. Ltd, Marrickville, NSW, Australia), which has a sensitivity greater than $0.35 \mathrm{mIU} /$ $\mathrm{ml}$, a working range of 5 to $150 \mathrm{mIU} / \mathrm{ml}$ and no crossreaction with hCG up to $50000 \mathrm{mIU} / \mathrm{ml}$. The molecular weight of hCG $\beta$ was assumed to be $22 \mathrm{kDa}$ and a conversion factor $1 \mathrm{IU}=45.45$ pmoles was used to convert results to molar equivalents.

hCG $\beta c f$ was estimated by an IRMA which has been previously described (de Medeiros et al. 1992a). A specific polyclonal antibody (DeM3) was used as the capture antibody and iodinated monoclonal antibody $32 \mathrm{H} 2$, which is directed against epitopes of both hCG $\beta$ and hCG $\beta c f$, was used for detection. This assay has a sensitivity of $1.5 \mathrm{pmol} / 1$, a working range of 5 to $1500 \mathrm{pmol} / 1$ and cross-reaction, on a molar basis, with hCG, hCG $\beta$, hCG $\alpha$ and $\mathrm{hLH} \beta$ of $2 \cdot 1,5 \cdot 3,0 \cdot 6$ and $0 \cdot 018 \%$ respectively.

Creatinine was determined in urine using the Beckman creatinine reagent kit with the Beckman Creatinine Analyser 2 (Beckman Instruments Inc., Fullerton, CA, USA).

\section{Pharmacokinetics}

The serum hCG concentrations were initially plotted on semilogarithmic graph paper and pronounced distribution 
kinetics were noted. The decline in the serum hCG concentrations $(\mathrm{C})$ could be described mathematically by either a bi- (1) or a tri-exponential equation (2),

$$
\begin{gathered}
\mathrm{C}=\mathrm{Ae}^{-\alpha \mathrm{t}}+\mathrm{Be}^{-\beta \mathrm{t}} \\
\mathrm{C}=\mathrm{Ae}^{-\alpha \mathrm{t}}+\mathrm{Be}^{-\beta \mathrm{t}}+\mathrm{Ce}^{-\gamma \mathrm{t}}
\end{gathered}
$$

where $\mathrm{A}, \mathrm{B}$ and $\mathrm{C}$ are the coefficients and $\alpha, \beta$ and $\gamma$ are the exponents of the equations. These equations were fitted to the serum hCG concentration-time data by non-linear least squares regression (Prism v.2, GraphPad Software Inc., San Diego, CA, USA) using both unweighted and weighted $1 / \mathrm{C}^{2}$ procedures. The biexponential equation with weighting $1 / \mathrm{C}^{2}$ was chosen as the most appropriate model based on the analysis of the relative residuals, minimisation of the sums of squares deviation and standard errors of the estimates of the coefficients and exponents. The model independent pharmacokinetic parameters of total systemic clearance, volume of distribution at steady-state and terminal half-life $\left(t^{1} / 2 \beta\right)$ were derived from calculation of the area under the serum hCG concentration-time curve (AUC) by the linear trapezoidal method and the terminal slope. The distribution phase half-life was calculated as $\ln 2 / \alpha$ and the initial volume of distribution $\left(\mathrm{V}_{\mathrm{C}}\right)$ as dose/A+B. The fraction of the $\mathrm{r}-\mathrm{hCG}$ dose excreted unchanged was the amount excreted in urine to $138 \mathrm{~h}$ divided by the dose administered and the renal clearance was the product of the fraction excreted unchanged and the total systemic clearance. Mean residence time (MRT) was calculated as AUMC/AUC where AUMC is the area under the product of serum hCG concentration $\times$ time and time curve.

\section{Results}

\section{Serum and urinary $h C G$ and $h C G \beta$}

Serum collected prior to infusion of recombinant hCG had no detectable hCG or hCG $\beta$. Human chorionic gonadotropin was detected in the first sample collected, $5 \mathrm{~min}$ after infusion, rising to a mean peak level after $10 \mathrm{~min}$ and then declining over a period of $105 \mathrm{~h}$ (Fig. 1a). The maximum concentration of hCG excreted in the urine (754 \pm 177 pmoles $/ \mathrm{mmol}$ creatinine; mean \pm s.E.M.) was found to occur in the first of the 6-hourly urine samples from 4 subjects (Fig. 1b). Although hCG $\beta$ immunoreactivity was detected in both the serum and urine samples (results not shown), the levels were below the r-hCG crossreaction in the assay, which we found to be $1.96 \%$, and therefore irrelevant.

\section{Gel filtration}

Gel filtration of the r-hCG on Superdex 75 resulted in one major hCG immunoreactive peak in fractions 51-67 and
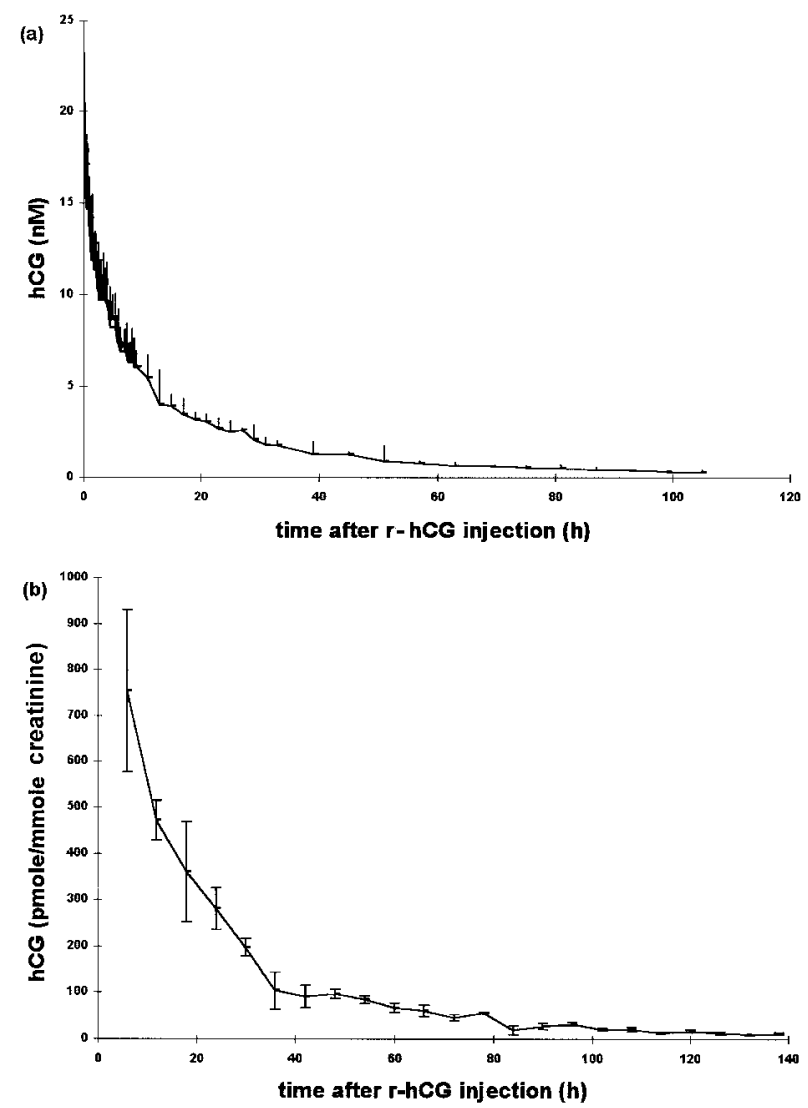

Figure 1 hCG concentration (mean \pm S.E.M.), measured by immunoradiometric assay, in (a) the serum of six healthy female subjects and (b) the urine of four of the subjects, after an intravenous injection of r-hCG (2 mg).

relatively minor hCG $\beta$ cf immunoreactivity $(0 \cdot 006 \%$ of hCG activity, calculated on a molar basis) in fractions 79-90, which corresponded to the elution fractions of purified hCG $\beta c f$. Rechromatography of the pooled fractions $79-90$ resulted in $70 \%$ recovery of the hCG $\beta \mathrm{cf}$ immunoreactivity. The true nature of the low molecular weight peak has not been characterized. Its presence has not been reported by the manufacturer and we are unsure of its origin. However, in comparison to the levels measured in the urine of the subjects, the estimated 3 pmoles of hCG $\beta c f$ immunoreactivity present in the $2 \mathrm{mg}$ r-hCG injected, was insignificant.

r-hCG and hCG $\beta$ immunoreactive peaks could not be resolved by chromatography on the Superdex 75 column (Fig. 2a). Therefore, when urine samples were chromatographed, fractions containing both these forms (51-70) were pooled prior to hCG and hCG $\beta$ assay. However, hCG $\beta$ cf immunoreactive fractions (79-90) were well resolved from $\mathrm{r}-\mathrm{hCG}$ and hCG $\beta$ as shown in both the elution profiles of chromatographed standards (Fig. 2a) and 
(a)

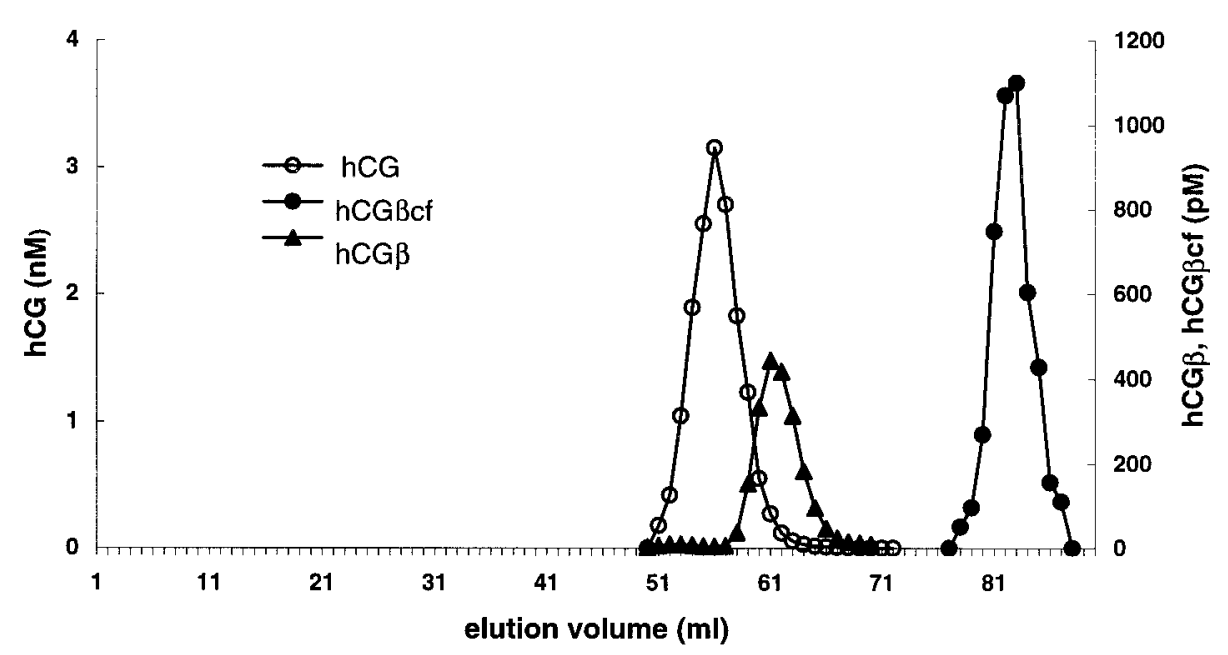

(b)

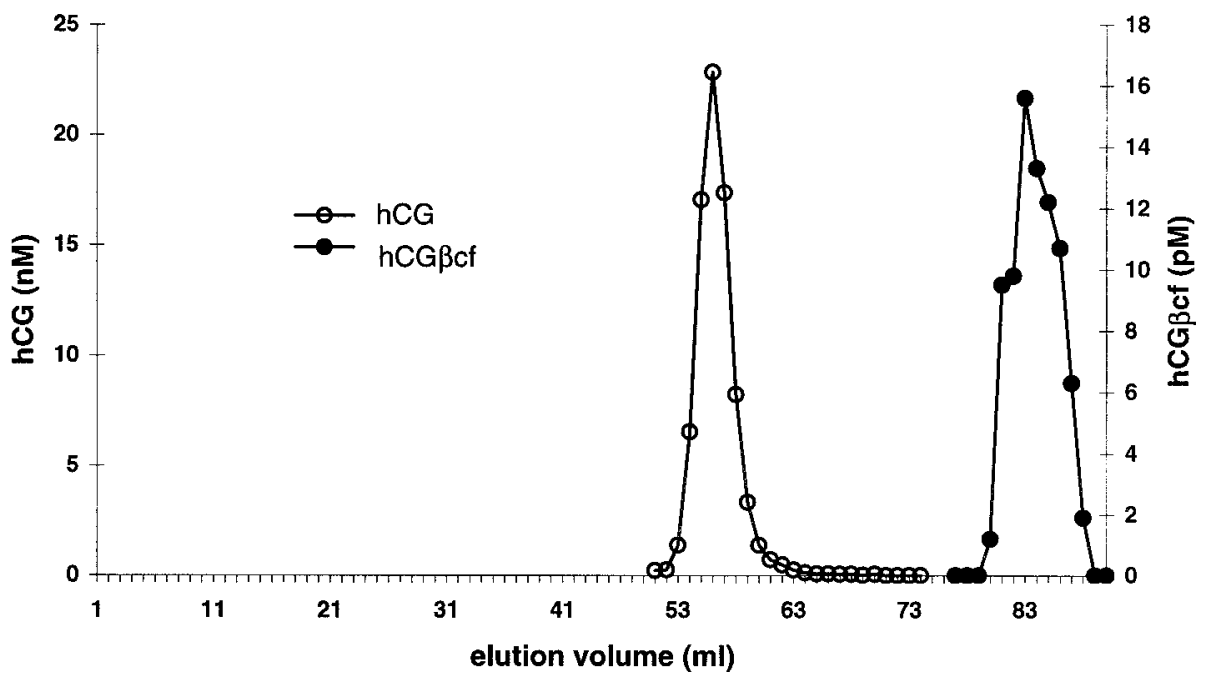

Figure 2 Elution profiles of (a) r-hCG, hCG $\beta$ and hCG $\beta$ cf standards and (b) a urine sample collected after injection of r-hCG, when subjected to gel chromatography on a Superdex 75 (16/60) column, equilibrated and run with $150 \mathrm{mM}$ ammonium bicarbonate.

a urine sample collected from a subject after injection of r-hCG (Fig. 2b). Therefore, hCG $\beta$ cf assay of these fractions, after pooling, avoided any crossreaction with urinary hCG. The values were corrected for recovery by multiplying the total hCG $\beta c f$ detected in the chromatographed urine by the total hCG in the equivalent volume of urine, prior to concentration and chromatography, and dividing by the hCG detected after chromatography. The hCG $\beta c f$ excretion profiles for the four subjects showed considerable intersubject variability (Fig. 3a-d). The mean amount of hCG $\beta c f$ excreted in the urine of 4 subjects over the $138 \mathrm{~h}$ period after $\mathrm{r}-\mathrm{hCG}$ infusion was 912 pmoles, ranging from 423 to 1503 pmoles (Fig. 3e). That is, the quantity of hCG $\beta c$ produced is only $1.7 \%$ (range 0.8 $2 \cdot 9 \%$ ) of the r-hCG injected and $12 \cdot 2 \%$ (range $8 \cdot 5-21 \cdot 7 \%$ ) of the hCG dimer excreted in the urine. The ratio of hCG $\beta$ cf to the intact hCG excretion increased from $3 \cdot 1 \pm 1 \cdot 7 \%$ (mean \pm S.E.M.) in urine collected on day 1 to $76 \cdot 0 \pm 34 \cdot 3 \%$ (mean \pm s.E.M.) on day 5 , after $\mathrm{r}$-hCG infusion (Fig. 3f).

\section{Pharmacokinetics}

The bi-exponential equation with weighting of the reciprocal of the square of the concentration provided the best and simplest mathematical description of the decline in serum hCG concentrations, following the intravenous dose. The total systemic clearance $(\mathrm{Cl})$ was $226 \pm 18 \mathrm{ml} / \mathrm{h}$ (mean \pm S.D.), the initial volume of distribution $\left(\mathrm{V}_{\mathrm{c}}\right)$ was $3.4 \pm 0.7$ litres, the volume of distribution at steady state 
(a)

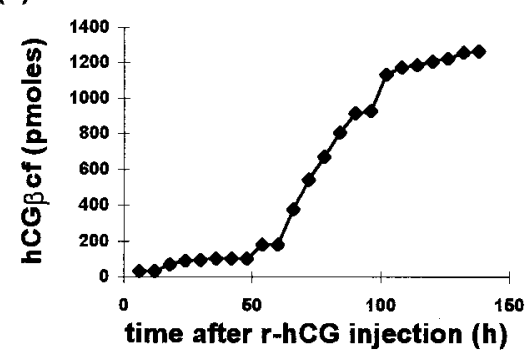

(c)

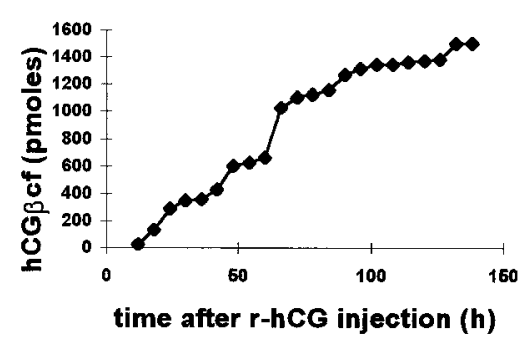

(e)

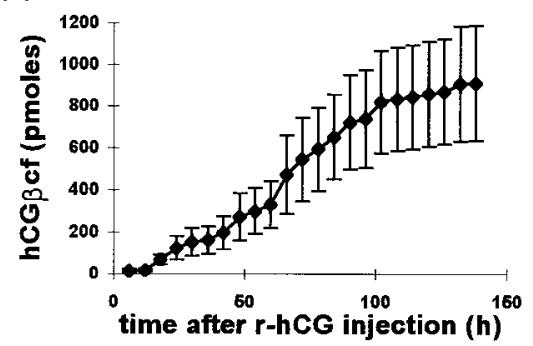

(b)

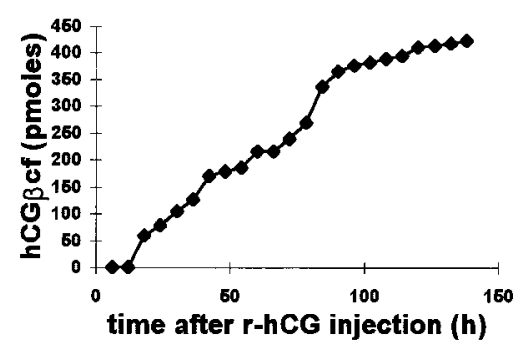

(d)

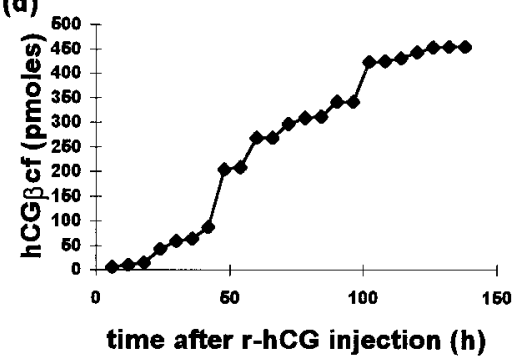

(f)

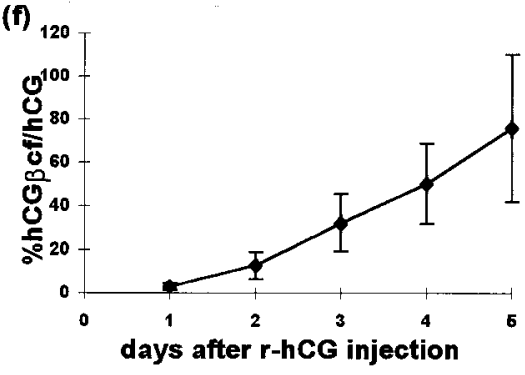

Figure $3(a, b, c, d)$ The cumulative sum of hCG $\beta c f$ detected in six-hourly urine samples, collected from four healthy female subjects, after an intravenous injection of $2 \mathrm{mg}$ r-hCG. The urine was subjected to gel chromatography prior to being assayed. The value of hCG $\beta c f$ was corrected for recovery as described in Results. (e) The cumulative sum of the total hCG $\beta c f$ excreted in six-hourly urine samples of the four subjects (means \pm S.E.M.). (f) hCG $\beta c f$ excreted daily in urine samples collected from the same four subjects and expressed as a percentage (mean \pm S.E.M.) of hCG detected in the same sample.

$\left(\mathrm{V}_{\mathrm{SS}}\right)$ was $6 \cdot 5 \pm 1 \cdot 15$ litres, the initial half-life $\left(\mathrm{t}_{1 / 2 \alpha}\right)$ was $4.5 \pm 0.7 \mathrm{~h}$, the terminal half-life $\left(\mathrm{t}_{1 / 2}\right)$ was $29 \cdot 0 \pm 4.6 \mathrm{~h}$ and the mean residence time (MRT) was $28.6 \pm 3.6 \mathrm{~h}$ (Table 1). The fraction of dose excreted unchanged ( $\mathrm{fe}$ ) and the renal clearance rate $(\mathrm{Clr})$ in the 4 subjects were calculated to be $12 \cdot 9 \pm 3 \cdot 4 \%$ and $28 \cdot 75 \pm 6 \cdot 2 \mathrm{ml} / \mathrm{h}$ respectively (Table 1$)$.

\section{Discussion}

In this study, we have injected a recombinant preparation of hCG into healthy, non-pregnant female volunteers to demonstrate that the urinary hCG $\beta \mathrm{cf}$ is produced by the metabolism of the intact $\mathrm{r}-\mathrm{hCG}$ molecule. Our observation of the appearance of hCG $\beta c f$ in the urine of four female subjects, after receiving a dose of $\mathrm{r}-\mathrm{hCG}$, supports the view that it is derived from the metabolic processing of hCG. Previous studies of pregnant subjects have shown that hCG $\beta c f$ concentrations are $2-10$ times that of the hCG dimer, on a molar basis, in pregnancy urine (Birken et al. 1988, Blithe et al. 1988, Krichevsky et al. 1988, Wehmann et al. 1989, 1990, de Medeiros et al. 1992b). However, in this study, the hCG $\beta$ cf measured was only $12 \cdot 2 \%$ of the amount of hCG excreted in urine, suggesting that, in pregnancy, there may be more than one pathway responsible for the production of hCG $\beta$ cf. Trophoblastic tissue has been associated with the production of hCG $\beta \mathrm{cf}$ (Udagawa et al. 1998) as well as degradation of hCG (by nicking) to its subunits (Cole et al. 1993), which could account for the higher output of hCG $\beta c f$ in pregnancy. The overall low excretion of hCG $\beta c f$ in urine may reflect the fact that it is only an intermediate metabolite, which is metabolised further to fragments that are undetectable 
Table 1 Pharmacokinetic parameters of r-hCG, following intravenous dosing in 6 healthy subjects

\begin{tabular}{|c|c|c|c|c|c|c|c|c|}
\hline & $\mathbf{C l}(\mathrm{ml} / \mathrm{h})$ & $\mathbf{V}_{\mathbf{c}}(\mathrm{L})$ & $\mathbf{V}_{\mathbf{s s}}(\mathrm{L})$ & $\mathbf{t}_{1 / 2 \boldsymbol{\alpha}}(\mathrm{h})$ & $\mathbf{t}_{1 / 2}(\mathrm{~h})$ & MRT (h) & fe $(\%$ dose $)$ & $\operatorname{Clr}(\mathrm{ml} / \mathrm{h})$ \\
\hline 1 & 214 & $2 \cdot 76$ & $6 \cdot 07$ & $4 \cdot 2$ & $33 \cdot 6$ & $28 \cdot 4$ & $17 \cdot 3$ & 37 \\
\hline 2 & 216 & $2 \cdot 76$ & $4 \cdot 83$ & $4 \cdot 8$ & $25 \cdot 1$ & $22 \cdot 7$ & $10 \cdot 1$ & 22 \\
\hline 4 & 260 & $4 \cdot 6$ & $7 \cdot 82$ & $3 \cdot 9$ & $26 \cdot 3$ & $29 \cdot 9$ & $10 \cdot 5$ & 27 \\
\hline 5 & 225 & $3 \cdot 22$ & $6 \cdot 90$ & $4 \cdot 0$ & $30 \cdot 0$ & $30 \cdot 4$ & * & * \\
\hline 6 & 228 & $3 \cdot 68$ & $7 \cdot 59$ & $4 \cdot 5$ & $34 \cdot 9$ & $33 \cdot 2$ & * & * \\
\hline S.D. & 18 & 0.69 & $1 \cdot 15$ & $0 \cdot 7$ & $4 \cdot 6$ & $3 \cdot 6$ & $3 \cdot 4$ & $6 \cdot 2$ \\
\hline$\% \mathrm{CV}$ & 8 & 20 & 18 & 16 & 16 & 13 & 26 & 22 \\
\hline
\end{tabular}

$\mathrm{Cl}$, total systemic clearance; $\mathrm{V}_{\mathrm{C}}$, initial volume of distribution; $\mathrm{V}_{\mathrm{ss}}$, volume of distribution at steady state; $\mathrm{t}_{\mathrm{s} \alpha}$, initial half life; $\mathrm{t}_{\mathrm{s}}$, terminal half life; $\mathrm{MRT}$, mean residence time; fe, fraction of dose excreted unchanged in urine and $\mathrm{Clr}$, renal clearance.

*Urine volume not available.

by the hCG $\beta$ cf immunoassay, as suggested by Wehmann et al. (1989), when they recovered only $8 \%$ of injected hCG $\beta c f$ in the urine of eight subjects.

r-hCG, injected i.v., exhibited a multi-exponential serum disappearance curve, as reported in previous studies for the disappearance of endogenous hCG, post-partum (Midgely \& Jaffe 1968, Yen et al. 1968, Korhonen et al. 1997) and urinary hCG (Rizkallah et al.1969, Wehmann \& Nisula 1981). The studies, where urinary hCG was injected i.v., reported biphasic disappearance curves, with a fast component, $t_{1 / 2} 5-6 \mathrm{~h}$, and a slow component, $t_{1 / 2}$ 24-32 h. Similarly, the studies of postpartum hCG reported a fast component of 3.6-11 h and a slow component of $18-37 \mathrm{~h}$. Our data using $\mathrm{r}-\mathrm{hCG}$ are similar to these values and suggest that there is no difference in the pharmacokinetics of $\mathrm{r}-\mathrm{hCG}$ compared with hCG derived from endogenous material. In addition, Korhonen et al. (1997) reported a third component, with $t_{1 / 2}=53 \mathrm{~h}$.

The percentage of injected hCG excreted in the urine, as the dimer, has been reported to vary from $17 \%$ to $28 \%$ (Wide et al. 1968, Wehmann \& Nisula 1981). We also found a variable fraction of $\mathrm{r}-\mathrm{hCG}$ excreted $(10 \cdot 1-17 \cdot 3 \%)$, with a lower mean percentage. This may reflect a variation in the glycosylation of the recombinant protein, compared with the urine-derived hCG used in the previous studies. Alternatively, the difference may be the result of the immunoassays used in the studies, and their ability to detect the various isoforms of hCG.

The renal clearance rate determined by Wide et al. (1968) was $0.77 \mathrm{ml} / \mathrm{min}$ in the first $6 \mathrm{~h}$ and $0.64 \mathrm{ml} / \mathrm{min}$ in the $7-24 \mathrm{~h}$ period, when an immunoassay was used, and $0.39 \mathrm{ml} / \mathrm{min}$ and $0.34 \mathrm{ml} / \mathrm{min}$, for the same respective periods, when calculated from bioassay results. Wehmann \& Nisula (1981), using highly purified urinary hCG, reported the renal clearance rate to be $0.7 \mathrm{ml} / \mathrm{min}$. The lower renal clearance rate determined in our study $(0.48 \mathrm{ml} / \mathrm{min})$ may reflect either the difference in the abundance of various isoforms, or that the urinary preparations of hCG, used in the other studies, may contain higher amounts of nicked hCG, which has a shorter half-life.

In conclusion, we have demonstrated for the first time, that the pharmacokinetic parameters of $\mathrm{r}-\mathrm{hCG}$ are similar to those of urinary hCG. In addition we report that $\mathrm{hCG} \beta \mathrm{cf}$ is a metabolite of $\mathrm{r}-\mathrm{hCG}$.

\section{Acknowledgements}

We wish to thank Serono Australia Pty. Limited for their financial support. We also wish to thank Ms Michele Kolo and Ms Anna Maria Carrera for their technical support.

\section{References}

Amr S, Wehmann RE, Birken S, Canfield RE \& Nisula BC 1983 Characterization of a carboxyterminal peptide fragment of the human choriogonadotropin $\beta$-subunit excreted in the urine of a woman with choriocarcinoma. Journal of Clinical Investigation 71 329-339.

Birken S, Armstrong EG, Gawinowicz-Kolks MA, Cole LA, Agosto GM, Krichevsky A, Vaitukaitis JL \& Canfield RE 1988 Structure of the human chorionic gonadotropin $\beta$-subunit fragment from pregnancy urine. Endocrinology 123 572-583.

Birken S, Gawinowicz MA, Kardana A \& Cole LA 1991 The heterogeneity of human chorionic gonadotropin (hCG). II. Characteristics and origin of nicks in hCG reference standards. Endocrinology 129 1551-1558.

Blithe DL, Akar AH, Wehmann RE \& Nisula BC 1988 Purification of $\beta$-core fragment from pregnancy urine and demonstration that its carbohydrate moieties differ from those of native human chorionic gonadotropin. Endocrinology 122 173-180.

Cole LA 1997 Immunoassay of human chorionic gonadotropin, its free subunits and metabolites. Clinical Chemistry 43 2233-2243.

Cole LA \& Birken S 1988 Origin and occurrence of human chorionic gonadotropin $\beta$-subunit core fragment. Molecular Endocrinology 2 825-830

Cole LA, Park S-Y \& Braunstein GD 1993 The deactivation of hCG by nicking and dissociation. Journal of Clinical Endocrinology and Metabolism 76 704-710. 
Kardana A, Taylor ME, Southall PJ, Boxer GM, Rowan AJ \& Bagshaw KD 1988 Urinary gonadotropin peptide isolation and purification, and its immunohistochemical distribution in normal and neoplastic tissues. British Journal of Cancer 58 282-286.

Kardana A, Elliott MM, Gawinowicz MA Birken S \& Cole LA 1991 The heterogeneity of human chorionic gonadotropin (hCG). I. Characteristics of peptide heterogeneity in 13 individual preparations of hCG. Endocrinology 129 1541-1550.

Kato Y \& Braunstein GD $1988 \beta$ core fragment is a major form of immunoreactive urinary chorionic gonadotropin in human pregnancy. Journal of Clinical Endocrinology and Metabolism 66 1197-1201.

Korhonen J, Alfthan H, Ylöstalo P, Veldhuis J \& Stenman U-H 1997 Disappearance of human chorionic gonadotropin and its $\alpha$ and $\beta$-subunit after term pregnancy. Clinical Chemistry 43 2155-2163.

Krichevsky A, Armstrong EG, Schlatterer J, Birken S, O'Connor J, Bikel K, Silverberg S, Lustbader JW \& Canfield RE 1988 Preparation and characterization of antibodies to the urinary fragment of human chorionic gonadotropin $\beta$-subunit. Endocrinology 123 584-593.

Lefort GP, Stolk JM \& Nisula BC 1986 Renal metabolism of the beta-subunit of human choriogonadotropin in the rat. Endocrinology 119 924-931.

de Medeiros SF, Amato F, Matthews CD \& Norman RJ 1992a Comparison of specific immunoassays for detection of the $\beta$-core human chorionic gonadotrophin fragment in body fluids. Journal of Endocrinology 135 161-174.

de Medeiros SF, Amato F, Matthews CD \& Norman RJ $1992 b$ Urinary concentrations of $\beta$-core fragment of hCG throughout pregnancy. Obstetrics and Gynecology 80 223-228.

Midgley AR Jr \& Jaffe RB 1968 Regulation of human gonadotropins: II. Disappearance of human chorionic gonadotropin following delivery. Journal of Clinical Endocrinology and Metabolism 28 1712-1718.

Puisieux A, Bellet D, Troalen F, Razafindratsita A, Lhomme C \& Bidart JM 1990 Occurrence of fragmentation of free and combined forms of the beta-subunit of human chorionic gonadotropin. Endocrinology 126 687-694.

Rizkallah T, Gurpide E \& Vande Wiel RL 1969 Metabolism of hCG in man. Journal of Clinical Endocrinology and Metabolism 29 92-100.

Udagawa A, Okamoto T, Nomura S, Matsuo K, Suzuki H \& Mizutani S 1998 Human chorionic gonadotropin beta-core fragment is present in the human placenta. Molecular and Cellular Endocrinology 139 171-178.

Wehmann RE \& Nisula BC 1981 Metabolic and renal clearance rates of purified human chorionic gonadotropin. Journal of Clinical Investigation 68 184-194.

Wehmann RE, Blithe DL, Flack MR \& Nisula BC 1989 Metabolic clearance rate and urinary clearance of purified $\beta$-core. Journal of Clinical Endocrinology and Metabolism 69 510-517.

Wehmann RE, Blithe DL, Akar AH \& Nisula BC 1990 Disparity between $\beta$-core levels in pregnancy urine and serum: implications for the origin of urinary $\beta$-core. Journal of Clinical Endocrinology and Metabolism 70 371-378.

Wide L, Johannisson E \& Tillinger KG 1968 Metabolic clearance rate of human chorionic gonadotrophin administered to non pregnant women. Acta Endocrinologica 59 579-594.

Yen SSC, Llerena O, Little B \& Pearson OH 1968 Disappearance rates of endogenous luteinizing hormone and chorionic gonadotropin in man. Journal of Clinical Endocrinology and Metabolism 28 1763-1767.

Received 29 June 1999

Accepted 27 October 1999 